\title{
"NÃO POSSO MAIS: EU QUERO É VIVER NA ORGIA": MALANDRAGEM FEMININA E REJEIÇÃO DO TRABALHO EM SAMBAS DAS DÉCADAS DE 1930 E 40
}

\section{Cilene Margarete Pereira}

\begin{abstract}
Resumo: No fim da década de 1920, sambistas do bairro do Estácio de Sá (Rio de Janeiro) impõem uma nova modalidade de samba, cadenciado para os desfiles de blocos e para o carnaval de rua. Dessa geração descendem os sambistas das décadas seguintes, encontrando no Rádio um importante veículo de difusão cultural que ajudaria na "consolidação" do samba como elemento de nacionalidade e na emergência de grandes compositores como Noel Rosa, Ataulfo Alves e Wilson Batista. O objetivo deste artigo é examinar, a partir de algumas letras de sambas das décadas de 1930 e 40 - tendo como ponto de partida a canção "Oh, Seu Oscar!” (1940), de Wilson Batista e Ataulfo Alves -, a oposição entre mundo regular e ordeiro (no qual se incluem a constituição da família e o trabalho honesto) e o universo da malandragem, dando destaque à tópica da "mulher da orgia”.
\end{abstract}

Palavras-chave: Samba. Malandragem. Personagens. Trabalho. Família.

\section{DO SAMBA ANTIGO AO "SAMBA DO ESTÁCIO"}

Em Acertei no Milhar: samba e malandragem no tempo de Getúlio (1882), Claudia Matos identifica duas gerações do samba carioca: a primeira, do início do século XX, é chamada por ela de "samba primitivo", sendo seus compositores os "pais" de "Pelo Telefone". O samba, conforme observado pelo próprio Donga, era bem próximo ao maxixe: "fiz o samba, não procurando me afastar muito do maxixe, música que estava bastante em voga." (DONGA apud MATOS, 1982, p. 39). Se o depoimento do sambista reforça a composição rítmica de "Pelo Telefone", afirma também o interesse comercial na peça, construída para se adequar aos padrões de um público já acostumado ao maxixe. ${ }^{2}$ Desse "grupo primitivo" faziam parte, além de Donga, Sinhô, João da Baiana e Caninha, frequentadores da casa da baiana Tia Ciata.

Em meados da década de 1920, surge a segunda geração de sambistas, conhecida como "samba do Estácio". No bairro do Estácio surgiria aquela considerada a primeira escola de samba, a "Deixa Falar", fundada por Ismael Silva e outros bambas, como Nilton Bastos, Bide, Mano Rubem, Mano Edgar, Baiaco e Brancura.

A nova modalidade de samba que eles começaram a fazer na década de 20 se amolava melhor às necessidades carnavalescas, naquele tempo em que o carnaval se popularizava,

\footnotetext{
${ }^{1}$ Doutora em Teoria e História Literária. Docente do Programa de Mestrado em Letras da Universidade Vale do Rio Verde (UNINCOR). E-mail: prof.cilene.pereira@unincor.edu.br.

${ }^{2}$ Claudia Matos observa que "no início do século [XX], o maxixe já conquistara um lugar nos hábitos culturais da classe média, chegando a motivar, nos anos 20, exibições de dança em palcos europeus." (MATOS, 1982, p. 39).
} 
tornava-se mais amplo e movimentado, e também, num certo sentido, mais brasileiro e mestiço. (MATOS, 1982, p. 39-40). ${ }^{3}$

Em entrevista a Sérgio Cabral, em As escolas de samba, Ismael Silva explica a diferença do "samba do Estácio" em oposição ao que se vinha praticando:

\begin{abstract}
É que quando comecei, o samba da época não dava para os grupos carnavalescos andarem na rua, conforme a gente vê hoje em dia. O estilo não dava para andar. Eu comecei a notar que havia essa coisa. O samba era assim: $\tan \operatorname{tantan} \tan \operatorname{tantan.~Não~dava.~Como~é~que~um~}$ bloco ia andar na rua assim? Aí, a gente começou a fazer um samba assim bum bum paticumbumprugurudum. (SILVA apud CABRAL, s/d, p.28).
\end{abstract}

A explicação de Ismael marca não só o novo ritmo, que dava ao samba mais "ginga, flexibilidade e mobilização simultâneas" (MATOS, 2012, p. 41), como deixava em evidência os espaços distintos de execução do samba, pois se os "sambistas primitivos" tinham os fundos das casas das velhas baianas; ${ }^{4}$ a turma do Estácio queria ocupar as ruas e os botequins. O samba do Estácio era, assim, um "samba carnavalesco", feito para o acompanhamento de cordões e blocos e, portanto, mais sincopado e que tratava de temas cotidianos com algum contorno cômico, como convinha à festa do Carnaval. Para Cláudia Matos,

É a direção do samba do Estácio que gera e fortalece as escolas de samba (...). O samba negro e proletário irrompia no asfalto travestido de príncipe, buscando patente de suas criações nas gravadoras da classe dominante branca e burguesa. (...). A "Deixa Falar" e outras escolas em desfile surgiram na avenida como formas de expressão em trânsito, movimentando-se na fronteira de culturas e classes. (MATOS, 1982, p. 42).

A partir da década de $1930,{ }^{5}$ tem-se o que se pode chamar de desdobramento in continuum da turma do Estácio, pois o samba, a partir de sua exposição no asfalto e na indústria da música, intensifica-se como produto cultural, difundindo-se como veículo de expressão de uma nacionalidade.

\footnotetext{
${ }^{3}$ Esse aspecto é também apontado por Carlos Didier ao observar que os sambas dos compositores do Estácio distinguiam-se "daqueles consagrados por Sinhô pelo menos por sua pulsação rítmica mais complexa. Enquanto estes guardavam vestígios de antigos maxixes, aqueles sambas que vinha do Estácio [se caracterizavam] pela agregação de mais de uma célula rítmica à marcação." (DIDIER apud SANDRONI, 2012, p. 34).

${ }^{4}$ A casa de Tia Ciata é descrita assim por Muniz Sodré: "Metáfora viva das posições de resistência adotadas pela comunidade negra, a casa continha os elementos ideologicamente necessários ao contato com a sociedade global: 'responsabilidade' pequeno-burguesa dos donos (o marido era profissional liberal valorizado e a esposa, uma mulata bonita e de porte gracioso); os bailes na frente da casa (já ali se executavam músicas e danças mais conhecidas, mais 'respeitáveis'), os sambas (onde atuava a elite da ginga e do sapateado) nos fundos; também nos fundos, a batucada - terreno próprio dos negros mais velhos, onde se fazia presente o elemento religioso...” (SODRÉ, 1998, p. 15).

5 "O período 1927-33 corresponde assim ao da ascensão e apogeu dos bambas do Estácio. A 'Deixa Falar' [escola de samba do Estácio] é dissolvida em 1931, ano que também é o da morte de Nílton Bastos; em 1933 há o rompimento entre [Francisco] Alves e Ismael; em 1935 o grupo estará totalmente dissolvido, com a morte de Brancura e Baiaco, e a prisão de Ismael, por envolvimento em uma briga." (SANDRONI, 2012, p. 189).
} 
Em Samba, o dono do corpo, Muniz Sodré observa a distinção entre o chamado "samba tradicional" e "samba produto cultural". Para ele, o "samba tradicional" teria como característico a improvisação feita sobre uma primeira parte, pois "os sambistas compunham só uma primeira parte da canção (samba de primeira parte), reservando à segunda um lugar de resposta social: ora a improvisação na roda de samba, ora o improviso dos diretores de harmonia na hora do desfile da escola.". (SODRÉ, 1998, p. 58). Na concepção de Sodré tal estrutura (primeira parte + improvisação) se daria tanto no espaço da roda de samba, lugar de excelência do partido-alto e de composições associadas aos "sambistas primitivos" (conforme "Pelo Telefone"), quanto na rua, a partir do andamento da Escola de Samba, o que nos levaria à composição melódica do "samba do Estácio".

Se o modo de composição entre as duas vertentes de samba observa uma mesma estrutura, apesar de variarem em termos melódicos; a geração seguinte, descendente do gingado e da síncope da turma de Ismael Silva, promoverá uma quebra estrutural, compondo um samba organizado para a forma do disco e que, portanto, "impõe peças prontas e acabadas" (SODRÉ, 1998, p. 58), sem direito a improvisações.

Sodré, no entanto, já identifica um processo inicial de industrialização do samba na gravação de "Pelo Telefone", considerando que "da canção folclórica (de produção e uso coletivos, transmitida por meios orais) transforma-se em música popular, isto é, produzida por um autor (indivíduo conhecido) e veiculada num quadro social mais amplo". (SODRÉ, 1998, p. 40).

Há de se destacar que o processo de industrialização, pós-geração do Estácio, tem proporções maiores, já que a Rádio se torna importante veículo de difusão cultural que ajuda na "consolidação" do samba e na emergência de grandes compositores, dentre os quais se destacam Noel Rosa, Wilson Batista, Geraldo Pereira, Ataulfo Alves, entre outros.

\begin{abstract}
Em meados dos anos 30 [do século XX], o samba-canção ou samba-de-meio-ano fixa-se como modalidade diversa do samba carnavalesco. Através das emissões radiofônicas, o novo gênero rapidamente conquista grandes contingentes do público urbano. Na mesma época, surge o samba-choro, produto híbrido que não chegou a se constituir como um estilo definido e duradouro. E um pouco mais tarde, o samba "Jogo proibido", lançado em 1936 na voz de Moreira da Silva, inaugura o gênero que viria a ser conhecido como samba-debreque. (MATOS, 1982, p. 45).
\end{abstract}

Em Feitiço decente: transformações do samba no Rio de Janeiro (1917-1933), Carlos Sandroni denomina essas duas gerações iniciais, apontadas por Claudia Matos, de "estilo antigo" e "estilo novo", observando também os espaços sociais ocupados por estes dois tipos de sambas: a casa de Tia Ciata (e de outras baianas) e blocos e botequins ${ }^{6}$ do bairro do Estácio, respectivamente.

\footnotetext{
${ }^{6}$ Sandroni explica que "o botequim é para o sambista do período um ponto tão habitual que é chamado às vezes de 'escritório' (...). Blocos e botequins possuem uma característica comum: são mais públicos, mais abertos socialmente, que a sala de jantar de Tia Ciata." (SANDRONI, 2012, p. 145-146).
} 
O tipo de samba que teria sido criado no Estácio logo se difundiu, influenciando os compositores de outras áreas da cidade, generalizando-se e tornando-se um sinônimo de samba moderno, de samba tal qual o reconhecemos hoje em dia. (SANDRONI, 2012, p. $133)^{7}$

Em se tratando da estrutura melódica distinta entre um estilo e outro, Sandroni observa ausências na bibliografia sobre o samba, reportando essa distinção, para alguns estudiosos, à audição apenas. A respeito disso, diz Sérgio Cabral: "É fácil: basta comparar uma velha gravação de um samba de Sinhô (ou do próprio "Pelo Telefone") com outra de um samba qualquer de autoria dos compositores do Estácio de Sá para estabelecer a diferença entre as duas formas de samba." (CABRAL, s/d, p. 21). Sérgio Cabral tem de fato razão e parte desta deve-se à explicação de Ismael Silva em entrevista concedida ao próprio Cabral, já citada neste texto. ${ }^{8}$

Para estudiosos como João Máximo e Carlos Didier, a diferença melódica se daria no uso (e na valorização) de instrumentos distintos, visto que o acompanhamento do samba da turma do Estácio seria feito, salvo algum cavaquinho e violão, especialmente por meio da percussão, com objetos "fabricados pelos próprios ritmistas ou por eles inventados", , enquanto que os sambistas primitivos optariam com "piano, flauta, clarineta, cordas e metais.” (MÁXIMO; DIDIER apud SANDRONI, 2012, p. 140).

Seja ou não a diferença originária da instrumentação, o fato é que, conforme observa Sodré no título de seu livro, Samba, o dono do corpo (1998), trata-se de uma distinção que, se pode ser sentida na audição, é revelada, sobretudo, na pulsação do corpo que obedece a marcações rítmicas próprias.

Para Sandroni, uma questão importante que passa pela distinção entre "estilo antigo" e "novo" diz respeito à própria estruturação dos versos no "samba folclórico" e no "samba popular". O "samba folclórico" está ligado, como já dissemos, à geração dos "sambistas primitivos" que improvisavam seus sambas a partir de uma primeira parte, às vezes de base folclórica. O "samba popular", associado à turma do Estácio e à profissionalização do sambista, é formatado para o mercado fonográfico, anulando as improvisações. Nesse caso, não haveria uma primeira parte que demandaria um complemento improvisado, mas duas partes compostas com o fim de formatar e fechar a canção.

\footnotetext{
7 Para reiterar a afirmativa, Sandroni cita o depoimento de sambistas consagrados como Candeia, da Portela, e Cartola, da Mangueira: "O Estácio era a escola mais velha, não vamos discutir isso. Fora do carnaval, o pessoal do Estácio vinha pra cá pro morro cantar samba, qualquer dia da semana. E nós tínhamos muito respeito a eles como os mestres do samba." (CARTOLA apud SANDRONI, 2012, p. $133)$.

${ }^{8}$ Analisando os livros Na roda do samba e Samba, de Vagalume e Orestes Barbosa, respectivamente, ambos em 1933, Sandroni resume, assim, a oposição entre "estilo antigo e novo": "Embora nenhum dos dois livros em questão fale explicitamente de uma diferença entre dois tipos de samba, ou entre samba e maxixe, fortes contrastes se manifestam neles entre duas maneiras de encarar o assunto (um valorizando a tradição, outro a modernidade), dois grupos de compositores a que se dá pesos diferentes (a turma da Tia Ciata e a do Estácio), duas reivindicações de origem (a Bahia e o Rio), dois personagens-símbolos (o bamba e o malandro)." (SANDRONI, 2012, p. 139).

${ }^{9}$ Em entrevista a Sérgio Cabral, eis a resposta de Bide sobre a invenção do surdo e do tamborim: "Bem, o tamborim eu encontrei, não tenho certeza se fui eu que inventei. O surdo, sim, foi ideia minha. E com uma lata de manteiga daquelas grandes, redondas, Compramos aros, botei um por fora outro por dentro, pregamos tacha e, assim entramos na Praça Onze.” (BIDE apud CABRAL, s/d, p. 30).
} 
(...) o samba folclórico (...) era em primeiro lugar a situação festiva; mas era também cada um dos estribilhos que se cantava, seguido das improvisações (que podiam identificar os sambas por não serem particulares a um estribilho dado). No contexto profissional, ao contrário, o samba é reificado, ganha autonomia em relação às pessoas que o criam - é por isso que começa a poder ser roubado e depois vendido. Como objeto independente, ele precisa demarcar as suas fronteiras: não mais o espaço aberto da improvisação, mas as duas partes definidas de uma vez por todas, letra e música devidamente escritas, publicadas e gravadas. (SANDRONI, 2012, p. 156).

Essa divisão imposta no samba popular a partir de 1930, em primeira parte (funcionado geralmente como um refrão) e segunda parte, ocasionou um "tipo específico de parceria real" entre os sambistas, "aquela em que um dos parceiros faz o estribilho e o outro, a segunda parte”, conforme observa Sandroni (2012, p. 156).

\title{
MALANDRAGEM FEMININA E REJEIÇÃO DO TRABALHO
}

Esse foi o processo de construção de "Oh, Seu Oscar!" (1939), samba de Wilson Batista e Ataulfo Alves, sucesso do carnaval de 1940 e vencedora do concurso de sambas carnavalescos organizado pelo DIP (Departamento de Imprensa e Propaganda), do governo Getúlio Vargas:

\author{
Cheguei cansado em casa do trabalho \\ Logo a vizinha me chamou: \\ Oh! seu Oscar \\ Tá fazendo meia hora \\ Que a sua mulher foi embora \\ E um bilhete deixou \\ Meu Deus, que horror \\ O bilhete dizia:
}

Não posso mais, eu quero é viver na orgia!

Fiz tudo para ver seu bem-estar

Até no cais do porto eu fui parar

Martirizando o meu corpo noite e dia

Mas tudo em vão: ela é da orgia

É, parei!

A primeira parte foi composta por Wilson e a segunda, por Ataulfo, tendo este contribuído com o verso título do samba, "Oh, Seu Oscar!", ao perceber que havia um "buraco na passagem do segundo para o terceiro verso (...)." (CABRAL, 2009, p. 50). A contribuição foi tão importante que redefiniu o nome do samba que se chamaria "Está fazendo meia hora". ${ }^{10}$ Percebe-se que a introdução do verso de Ataulfo resultou

\footnotetext{
${ }^{10} \mathrm{O}$ caso é narrado, segundo Cabral, pelo biógrafo de Wilson Batista, Bruno Ferreira. (Cf. CABRAL, 2009, p. 50).
} 
também em uma adaptação de linguagem, visto o tom coloquial da versão oficial: "Tá fazendo meia hora" ( $4^{\circ}$ verso da primeira parte).

A segunda parte do samba se adapta perfeitamente à primeira, esboçando a reclamação da personagem masculina quanto aos sacrifícios feitos pela mulher: "Cheguei cansado do trabalho" ( $1^{\mathrm{a}}$ parte) e "Até no cais do porto eu fui parar / martirizando o meu corpo noite e dia" ( $2^{\mathrm{a}}$ parte). Seu Oscar entende que a felicidade feminina está condicionada à família e à composição social do lar, denominações masculinas para "bem-estar". Mas o abandono dá-se, conforme sugere a canção, pela oposição entre desejo feminino ("Não posso mais, eu quero é viver na orgia!") e oferta masculina ("Fiz tudo para o seu bem-estar"). O que Seu Oscar oferta a sua mulher (um homem cansado e com seu corpo martirizado) não é o suficiente para mantê-la presa à vida doméstica, preferindo a orgia, sinônimo, aqui, "de vida boêmia, do modo de vida apreciado pelo malandro", sendo quase equivalente à malandragem. (SANDRONI, 2012, p. 163).

O que teríamos, na canção, é uma oposição entre as personagens feminina e masculina marcada por inversões relativas ao gênero (pelo menos conforme prevista pela moral burguesa cristã) nos modos de condução de suas vidas enraizados em duas figuras tradicionais do samba: o malandro (papel exercido, aqui, pela mulher) e o trabalhador, na linguagem malandra, o otário (Seu Oscar). Para Claudia Matos, paralela a esta dicotomia entre malandro e trabalhador,

\begin{abstract}
esboça-se a oposição entre sexo e prazer/casamento e família. Ora, esta mulher malandra recusa o papel de esposa, despreza o bem-estar material e parte em busca de liberdade e satisfação para o seu desejo, enquanto a opção do marido só lhe proporcionou o martírio do corpo, a anulação do desejo. Assumindo a postura do malandro, a mulher faz do marido (...) um verdadeiro otário. (...) ao procurar a orgia, ela parece seguir um caminho legítimo e natural - "ela é da orgia" - enquanto foi o homem que se enganou ao impor um caminho errado e inútil, que não levava a parte alguma: "até no cais do porto [ele foi] parar". (MATOS, 1982, p. 96, grifos da autora).
\end{abstract}

Assim, se na primeira parte do samba temos a constatação do abandono do eu lírico (e a inserção das vozes femininas - vizinha e mulher); ${ }^{11}$ na segunda parte, Ataulfo parece querer justificar o nome da personagem título, já que, segundo depoimentos colhidos por Sérgio Cabral, "Seu Oscar" "era uma gíria muito usada no Café Nice identificando o otário, o bobalhão...". (CABRAL, 2009, p. 50). ${ }^{12}$ Ou seja, a um homem do tipo "Oscar" só caberia este destino: a martirização do corpo e o abandono (como recompensa). A derrota masculina é finalizada com um sugestivo "É, parei”, conotando a imobilidade da personagem em todos os níveis: moral, social, amoroso, existencial.

Em busca da compreensão da figura feminina aí exposta, vale a pena nos determos no comentário de Matos acima, ressaltando o uso do verbo ser no presente do

${ }^{11}$ É interessante como Wilson Batista capta vozes dissonantes, aqui, ao apresentar um ser feminino acorrentado às malhas do padrão moral (reforço da voz de Seu Oscar) - por isso o verso "Meus Deus, que horror" parece ser um reflexo do pensamento de ambos - e seu contrário: a liberdade moral e sexual.

${ }^{12}$ Os depoimentos referidos por Cabral são os do compositor Roberto Martins e os dos estudiosos Zuza Homem de Melo e Jairo Severiano em A canção no tempo.

PEREIRA, Cilene Margarete. "Não posso mais: eu quero é viver na orgia”: malandragem feminina e rejeição do trabalho em sambas das décadas de 1930 e 40. Crítica Cultural - Critic, Palhoça, SC, v. 9, n. 1, p. 57-69,

jan./jun. 2014. 
indicativo no verso "Mas tudo em vão: ela é da orgia" (grifos nossos). Considerando, como observa a ensaísta, que a orgia é determinada como um "caminho legítimo e natural" da esposa de Seu Oscar, podemos afirmar que se trata, aqui, de uma tentativa de regeneração do ser malandro. Em outras palavras, Seu Oscar promove, com consequências negativas, sobretudo a ele, uma adequação frustrada da mulher malandra ao mundo familiar, organizado segundo regras bastante disciplinadoras quanto ao comportamento e espaço femininos. Tal concepção sempre foi legitimada por um discurso (erudito e também popular) que afirmava o antagonismo sexual:

\footnotetext{
Os homens estão do lado da razão e da inteligência que fundam a cultura; a eles cabe a decisão, a ação e, consequentemente, a esfera pública. As mulheres se enraízam na Natureza; elas têm o coração, a sensibilidade, a fraqueza também. (PERROT, 2005, p. 268 269).
}

Dentro dessa perspectiva "segregadora" impôs-se uma nítida divisão entre as atividades destinadas à mulher (ligadas todas ao território doméstico - das quais se inclui a maternidade) e as de funções estritamente masculinas (associadas ao espaço público). Enquanto Seu Oscar martiriza seu corpo, no cais, em busca da promoção do bem-estar feminino; sua esposa deveria manter-se nos limites da casa, exercendo funções domésticas e de apelo sentimental: "Mas tudo em vão: ela é da orgia". De algum modo, a constatação de Seu Oscar parece anunciar um erro estratégico, assumindo, em parte, a responsabilidade sobre a frustrada adaptação feminina. A temática da "mulher da orgia" é, nesse sentido, uma constante nas letras dos sambas, como vemos em "Vai, mulher da orgia" (1936), composição de Miguel Guarnieri e Roberto Martins:

\author{
Vai, vai, vai \\ Eu não culpado de você me abandonar \\ O destino de toda mulher da orgia \\ É penar, é penar \\ Foi você a flor que quis roubar minha alegria \\ E no meu coração deixou a nostalgia \\ Se o fogo da vida desfolhar sua beleza \\ Você há de sentir a lei da natureza \\ Em todo caminho perfumado e venturoso \\ Há sempre um abismo profundo e perigoso \\ Nesse mar da vida o destino é traiçoeiro \\ Às vezes sem querer o azar chega primeiro
}

Em "Vai, mulher da orgia", o recado é claro: "O destino de toda mulher da orgia / É penar, é penar". Talvez seja essa a solução final reservada à mulher de Seu Oscar - 
caso não haja o perdão do marido. ${ }^{13} \mathrm{Na}$ canção acima, temos a reafirmação de algo já visto em "Oh, Seu Oscar": a trajetória masculina de desilusão e imobilidade dá-se a partir da figura feminina que se configura como "um abismo profundo e perigoso" que, no entanto, deixa marcas emocionais no eu lírico: "no meu coração deixou a nostalgia". Essas mulheres são descritas, na análise que o sociólogo Manoel Berlinck faz das imagens femininas presentes nas letras de sambas, como aquelas que não possuem "contrato exclusivo com nenhum homem", desorganizando "as relações sociais do homem gerando a 'dor de cotovelo', a desconfiança e reforçando a prática da malandragem”. (BERLINCK, 1976, p. 109).

Para enfatizarmos ainda mais essa oposição criada entre as personagens malandra (mulher) e otária (Seu Oscar), na canção de Ataulfo Alves e Wilson Batista, vale a pena recorrer ao samba de Cyro de Souza, "Vida apertada".

\author{
Meu Deus, que vida apertada \\ Trabalho, não tenho nada \\ Vivo num martírio sem igual \\ A vida não tem encanto \\ Para quem padece tanto \\ Desse jeito eu acabo mal \\ Ser pobre não é defeito \\ Mas é infelicidade \\ Nem sequer tenho direito \\ De gozar a mocidade \\ Saio tarde do trabalho \\ Chego em casa semimorto \\ Pois enfrento uma estiva \\ Todo dia lá no 2 \\ No cais do porto \\ (Tadinho de mim: breque)
}

Essa canção esmiúça detalhes do dia-a-dia de sacrifícios feitos pelo Seu Oscar em busca do bem-estar feminino. A personagem do samba de Cyro de Souza é também um estivador que martiriza seu corpo ("Vivo num martírio sem igual"), no cais do porto, chegando ao lar "semimorto". Trabalhar, neste contexto, é algo apenas penoso que absorve as forças do homem e que não traz nenhuma compensação, material ou existencial: "Trabalho, não tenho nada"; "A vida não tem encanto".

A canção reforça uma ideia recorrente no mundo do samba, a rejeição ao trabalho, que ganha contorno na figura do malandro, ser que se define em primeiro lugar, segundo Sandroni, "por sua relação esquiva com o mundo do trabalho: trabalha o

\footnotetext{
${ }^{13} \mathrm{Na}$ esteira do sucesso de "Oh, Seu Oscar!", Wilson Batista e Ataulfo Alves promoveram o retorno das personagens na canção “A mulher do Seu Oscar" (1941), na qual temos a justificativa da personagem feminina para o abandono (provisório) do marido: "Onde eu dizia/ Vou-me embora pra orgia/ Era pro samba/ Sem segunda intenção/ Orgia de luz, de riso e alegria."
} 
mínimo possível, vive do jogo, das mulheres que o sustentam e dos golpes que aplica nos otários, sua contrapartida bem comportada." (SANDRONI, 2012, p. 158). ${ }^{14}$ Ocorre que

a rejeição ao trabalho esteia-se, para o sambista e para um amplo grupo proletário cuja visão de mundo ele expressa, num sentimento de descrédito e desilusão em relação às compensações oferecidas pelo trabalho tal como ele se dá em nosso sistema socioeconômico. (MATOS, 1982, p. 79).

Tal construção socioeconômica não permite, para trabalhadores assalariados e de baixa renda, qualquer tipo de deslocamento social, ${ }^{15}$ pois o trabalho objetiva "simplesmente obter o mínimo necessário à própria manutenção e à dos seus", completa Matos (1982, p. 79). Não se trabalha, pois, para o acúmulo de capital e para a satisfação do ócio, mas para um mínimo necessário à subsistência da família. E, às vezes, essa família não "reconhece" os esforços diários da labuta, levando o trabalhador, como no caso da canção de Wilson e Ataulfo, a uma série de lamentações diante do abandono feminino.

\begin{abstract}
Essa mulher e outras tantas que caíam na folia, com uma vida relativamente liberada das amarras convencionais, não eram, em hipótese alguma, compatíveis com a imagem idealizada pelo ministro do Trabalho Marcondes Filho, ao exaltar "a senhora do lar proletário". Muito menos se afinavam com o misto de esposa ideal e real concebida pelo jurista Cesarino Jr., de acordo com as "tradições virtuosas das matronas brasileiras". Essas mulheres "do barulho", "do balacobaco", infelicitavam a vida dos seus parceiros: trocavam, com facilidade, as prendas domésticas pela gandaia... (PARANHOS, 2011, p. 72).
\end{abstract}

A afirmativa de Paranhos faz constatar o que ele chama de "discurso alternativo" às vozes sintonizadas com a política do Estado Novo de exaltação do trabalho. ${ }^{16}$ As

\footnotetext{
${ }^{14}$ Para Matos, o senso comum designa que "malandro seria quem não trabalha ou não gosta de trabalhar, preferindo sobreviver à custa de expedientes matreiros e frequentemente desonestos." (MATOS, 1982, p. 77). Em entrevista a Moreira da Silva, Matos observa a definição singular deste de malandro: "malandro não é quem não faz nada, que assim seria muito difícil viver; é quem não pega no pesado. O estivador que carrega fardos o dia inteiro, o operário, o motorista de ônibus, não são malandros; já certos tipos de pequenos funcionários públicos, por exemplo, podem sê-lo. Moreira citou, como exemplo de profissão de malandro, a fiscalização da estiva. Há também os 'trabalhos' ilícitos, como a cafetinagem, o jogo, etc.”. (MATOS, 1982, p. 77).

${ }^{15}$ Matos chega a obsevar que uma análise dos sambas das décadas de 1930 a 50 mostra que o único deslocamento possível ao pobre é o reservado ao transporte público, por isso um número grande de canções tematizam esse deslocamento via bonde: "O que está contido na rejeição ao trabalho é a consciência de que a sociedade capitalista brasileira raramente permite o deslocamento do indivíduo negro dentro de sua hierarquia econômica e social. A possibilidade de tal deslocamento (...) só existe efetivamente e em maior escala a partir do estrato social pequeno-burguês, e está geralmente vedada ou grandemente dificultada para trabalhadores negros." (MATOS, 1982, p. 82).

16 "Gerar um 'novo homem', um cidadão modelar, ajustado aos princípios de cidadania incensados pelo Estado Novo, era tarefa prioritária do 'Brasil Novo' que se tentava forjar. Tornava-se imperioso espantar de uma vez por todas o fantasma da vadiagem ou da contestação ao sistema de trabalho reinante. Afinada por esse diapasão, a Constituição promulgada em 10 de novembro de 1937 assemelhava ociosidade a crime e prescrevia, no seu artigo 136, que 'o trabalho é um dever social'. Já o artigo 139 capitulava a greve como 'recurso antissocial', ato delituoso passível de prisão por 3 a 18 meses, mais as penas acessórias cabíveis, conforme estipulava o artigo 165 do Código Penal.” (PARANHOS, 2011, p. 62).
}

PEREIRA, Cilene Margarete. "Não posso mais: eu quero é viver na orgia”: malandragem feminina e rejeição do trabalho em sambas das décadas de 1930 e 40. Crítica Cultural - Critic, Palhoça, SC, v. 9, n. 1, p. 57-69, jan./jun. 2014. 
duas canções citadas ("Oh, Seu Oscar" e "Vida apertada") oferecem outra realidade, na qual o trabalho não é compensador. José Miguel Wisnik pontua que

\begin{abstract}
a malandragem sambística, nesse contexto [do Estado Novo], aparece como um mal a ser erradicado. (...) Através de um aliciamento indireto, o Departamento de Propaganda incentiva os sambistas a fazerem o elogio do trabalho contra a malandragem. Convite em grande parte fracassado, no entanto, e por uma razão que podemos entender bem. Embora alguns sambas procurem efetivamente assumir um ethós cívico no nível das letras, essa intenção é contradita pelo gesto rítmico, pelas pulsões sincopadas que (...) opõe um desmentido corporal ao tom hínico e à propaganda trabalhista. A tradição da malandragem resiste, de dentro da própria linguagem musical, à redução oficial, produzindo curiosas incongruências de letra e música, e sobrevive intacta ao Estado Novo. (WISNIK, 1992, p, 120).
\end{abstract}

Uma dessas incongruências é apontada por Paranhos na análise do samba "O amor regenera o malandro" (1940), de Sebastião Figueiredo:

\author{
Sou da opinião \\ De que todo malandro \\ Tem que se regenerar \\ Se compenetrar (e ainda mais: breque) \\ Que todo mundo deve ter \\ $\mathrm{O}$ seu trabalho para o amor merecer
}

Segundo o ensaísta, a impressão inicial de adesão à política de erradicação da malandragem "se desfaz ao acompanharmos a performance dos intérpretes, Joel e Gaúcho, no fecho da segunda estrofe", na qual "o uso do breque a duas vozes - breque que, neste caso, é anunciador de distanciamento crítico - bota por terra todo o blablabá estado-novista que parecia haver contagiado a gravação." (PARANHOS, 2011, p. 64$65)$.

\author{
Regenerado \\ Ele pensa no amor \\ Mas pra merecer carinho \\ Tem que ser trabalhador (que horror!: breque)
}

Em "Ganha-se pouco mas é divertido", de Wilson Batista e Cyro de Souza (1940), o dia a dia árduo do trabalhador, de segunda a sábado em uma fábrica, só é rompido pela emergência do domingo e da festa, momento compensador.

\footnotetext{
Ele trabalha de segunda a sábado

Com muito gosto sem reclamar

Mas no domingo ele tira o macacão,

Embandeira o barracão,

Bota a família pra sambar

Lá no morro ele pinta o sete
}

PEREIRA, Cilene Margarete. "Não posso mais: eu quero é viver na orgia": malandragem feminina e rejeição do trabalho em sambas das décadas de 1930 e 40. Crítica Cultural - Critic, Palhoça, SC, v. 9, n. 1, p. 57-69, jan./jun. 2014. 
Com ele ninguém se mete

Ali ninguém é fingido

Ganha-se pouco mas é divertido

Ele nasceu sambista

Tem a tal veia de artista

Carteira de reservista

E está legal com o senhorio

Não pode ouvir pandeiro não

Fica cheio de dengo

É torcida do Flamengo

Nasceu no Rio de Janeiro

Considerando o tipo de parceria entre os compositores aludida por Sandroni, é possível afirmar a autoria de cada uma das partes da canção: coube a Wilson o refrão (primeira parte) e ao parceiro Cyro, a segunda. Desse modo, temos Batista construindo a imagem dupla da personagem masculina: trabalhador e sambista. Ou seja, temos aqui uma duplicidade que nem sempre é vista no samba, já que sambista é quase sempre associado ao malandro, sobretudo a partir das criações do grupo do Estácio. ${ }^{17}$

Wilson Batista, malandro de primeira, constrói uma personagem operária que atende, diariamente ("de segunda a sábado"), à ordem do sistema ("sem reclamar"), padronizado e sem identidade pelo uso do uniforme ("macacão"). Mas esse mesmo operário tem uma válvula de escape: o samba, que não só expõe sua outra faceta ("põe a família para sambar") como o individualiza a partir de uma comunhão coletiva. A individualização ocorre por meio de sua dissociação ao mundo do trabalho (o mundo dos dominantes, do qual ele é só mais um dominado). Essa singularização do sujeito torna-se mais evidente na segunda parte do samba, na qual alguns caracteres são incorporados como reforço da composição trabalhador e sambista já anunciada por Wilson Batista na primeira parte:

\footnotetext{
Ele nasceu sambista

(...)

Não pode ouvir pandeiro não

(...)

É torcida do Flamengo

Nasceu no Rio de Janeiro
}

É interessante notar que os elementos caracterizadores da personagem são também responsáveis por colocá-lo em contato com uma comunidade maior, representada, na canção, por sua associação aos moradores do morro:

\footnotetext{
${ }^{17}$ A noção de malandro está associada à de sambista desde os anos 20 [do século passado]. A associação é simultânea ao processo de derivação do samba para sua versão rítmica 'moderna', aquela que se divulgou a partir dos fins da década de 20 nas criações do pessoal do Estácio. (MATOS, 1982, p. 39).
} 
Lá no morro ele pinta o sete

Com ele ninguém se mete

Ali ninguém é fingido

A segunda parte continua a promover a duplicidade da personagem, associando-a ao mundo da ordem, da qual o trabalho faz sem dúvida parte: "Carteira de reservista / E está legal com o senhorio". Cyro de Sousa desenvolve o tema de Wilson e o retoma, reafirmando o espaço do morro e do samba ("é divertido") como oposição ao "mundo lá fora" (“Ganha-se pouco"). A unir estes dois mundos está uma conjunção adversativa (mas) que parece afirmar a supremacia do morro em oposição ao mundo do asfalto; afinal, "ali ninguém é fingido".

\begin{abstract}
Apesar da tendência à idealização patente nestes versos, observa-se que eles configuram uma verdade particular à comunidade da favela e do samba, verdade que se identifica à noção de uma sinceridade ou autenticidade de todo o grupo: "ali ninguém é fingido". (MATOS, 1982, p. 32).
\end{abstract}

"Ganha-se pouco mas é divertido" revela, como nos lembra José Miguel Wisnik, que "a afirmação do ócio é para o negro a conquista de um intervalo mínimo entre a escravidão e a nova precária condição de mão de obra desqualificada e flutuante." (WISNIK, 1992, p. 119). O momento consagrado ao dançar e cantar (ao ócio e à celebração, portanto) aponta para a brecha mínima existente entre duas condições embrutecidas pela exploração e pelo trabalho alienado. Não se pode esquecer de que o samba, em sua função mais imediata, tem um caráter lúdico, promovendo, assim, um "território protegido das pressões externas, que é, simultaneamente, um território de prazer, com valores próprios, que procura preservar-se excluindo de si os fatores que representam opressão e desprazer." (MATOS, 1982, p. 31).

O samba pode ser entendido, dentro dessa visão intervalar mínima, como uma espécie de "agente unificador e mantenedor de uma identidade sociocultural do grupo que o pratica", ganhando um "estatuto de patrimônio coletivo a ser cultuado e preservado”. (MATOS, 1982, p. 31). Para Muniz Sodré, “o samba é o meio e o lugar de uma troca social, de expressão de opiniões, fantasias e frustrações, de continuidade de uma fala (negra) que resiste à expropriação cultural". (SODRÉ, 1998, p. 59). Assim, ele se qualifica como índice de uma resistência mínima ainda que pareça apontar para a mitificação da pobreza feliz como em "Ganha-se pouco mas é divertido".

\title{
REFERÊNCIAS
}

BERLINCK, Manoel Tosta. Sossega leão! Algumas considerações sobre o samba como forma de cultura popular. In: Contexto. São Paulo: novembro de 1976, N. ${ }^{\circ} 1$.

CABRAL, Sérgio. As escolas de samba. Rio de Janeiro: Ed. Fontana, s/d.

MATOS, Cláudia. Acertei no milhar: samba e malandragem no tempo de Getúlio. Rio de Janeiro: Paz e Terra, 1982.

PARANHOS, Adalberto de Paula. Espelhos partidos: samba e trabalho no tempo do "Estado Novo".

Projeto História. Dezembro de 2011. N. 43. 
PERROT, Michelle. As mulheres ou os silêncios da história. Trad. Viviane Ribeiro. Bauru/SP: EDUSC, 2005.

SANDRONI, Carlos. Feitiço decente: transformações do samba no Rio de Janeiro (1917-1933). $2^{\mathrm{a}}$ ed. Rio de Janeiro: Zahar, 2012.

SEVERINO, Jairo; MELlO, Zuza Homem de. A canção no tempo: 85 anos de músicas brasileiras (volume 1: 1901-1957). Rio de Janeiro: Editora 34, 1997.

SODRÉ, Muniz. Samba, o dono do corpo. Rio de Janeiro: Mauad, 1998.

WISNIK, José Miguel. Algumas questões de música e política no Brasil. In: BOSI, Alfredo (org.).

Cultura brasileira: temas e situações. São Paulo: Ática, 1992.

Recebido em: 04/02/2014. Aprovado em 15/06/2014.

Title: "Não posso mais: eu quero é viver na orgia": female trickery and work rejection in sambas from the 1930s and 40s

Abstract: At the end of the 1920s, samba players from the Estácio de Sá neighboorhood (In Rio de Janeiro) impose a new mode of samba, played to the rhythm for the official street parades and street Carnival parades. From this generation, descend the samba players of the following decades, who found the radio to be an important vehicle to diffuse it culturally and to help "consolidate" the samba as an element of nationality and the in the emerging of great composers, such as Noel Rosa, Ataulfo Alves and Wilson Batista. The objective of this study is to examine, from some samba lyrics from the 1930s and 40s having as a starting point a song named "Oh, Seu Oscar!" (1940), by Wilson Batista and Ataulfo Alves - , the opposition between regular world and orderly world (in which are included the family constitution and honest work) and the universe of trickery, giving emphasis to the topic of the "orgy woman."

Keywords: Samba. Trickery. Characters. Work. Family.

PEREIRA, Cilene Margarete. "Não posso mais: eu quero é viver na orgia”: malandragem feminina e rejeição do trabalho em sambas das décadas de 1930 e 40. Crítica Cultural - Critic, Palhoça, SC, v. 9, n. 1, p. 57-69, jan./jun. 2014. 